\title{
EFFECT OF FUNCTIONAL STATUS ON THE QUALITY OF LIFE OF PATIENTS WITH STROKE: A META-ANALYSIS
}

\author{
Anwar Wahyudi'), Didik Gunawan Tamtomo'), RB. Soemanto3) \\ ${ }^{1)}$ Masters Program in Public Health, Universitas Sebelas Maret \\ 2)Faculty of Medicine, Universitas Sebelas Maret \\ 3)Faculty of Social and Political Sciences, Universitas Sebelas Maret
}

\begin{abstract}
Background: Patients with stroke may become disabled and have specific problems due to the physical and mental disability. Stroke is also prone to loss of productivity, which imposes their quality of life. The aim of this study was to evaluate the effect of functional status on the quality of life in stroke patients.

Subjek dan Metode: A systematic review and meta-analysis was conducted by collecting articles from Clinical Key, DOAJ, PubMed, Science Direct, Proquest, Scopus, and Google Scholar databases. The articles were filtered using PICO model, including: (1) Population= post stroke patients, (2) Intervention= good functional status, (3) Comparison $=$ poor functional status, and (4) Outcome $=$ quality of life. Keywords used "functional status" AND "quality of life" AND "stroke". Articles included for this study were full text, cross sectional study, wrote in English language, published from year 1991 to 2020, and reporting $\beta$-coefficient. The articles were collected using PRISMA flow diagram. Quantitative data were analyzed by Review Manager (RevMan) 5.3.

Results: There were 5 studies with 620 stroke patients from Thailand, Taiwan, Turkey, and Pakistan. This meta-analysis study showed that functional status was positively associated with quality of life of stroke patients $(\beta$-coefficient $=0.63 ; 95 \% \mathrm{CI}=$ 0.52 to $1.08 ; \mathrm{p}=0.0001$ ).
\end{abstract}

Conclusion: Functional status is positively associated with quality of life of stroke patients.

Keywords: functional status, quality of life, stroke

Correspondence:

Anwar Wahyudi. Masters Program in Public Health, Universitas Sebelas Maret. Jl. Ir Sutami 36A, Surakarta 57126, Central Java. Email: arwanwahyudi851@gmail.com. Mobile : +62813106121049 .

The $8^{\text {th }}$ International Conference on Public Health Solo, Indonesia, November 17-18, 2021 | 21 https://doi.org/10.26911/AB.Epidemiology.ICPH.08.2021.01 